\title{
Elastase Inhibitory Activity, Determination of Total Polyphenol and Determination of Total Flavonoids, and Pharmacognosy Study of Faloak Plant (Sterculia quadrifida R.Br) from East Nusa Tenggara-Indonesia
}

\author{
Sofiah Yunita Radjah', Kunia Sari Setio Putri' ${ }^{2}$, Berna Elya ${ }^{1, *}$
}

Sofiah Yunita Radjah', Kunia Sari Setio Putri ${ }^{2}$, Berna Elya ${ }^{1, *}$

\section{'Department of Pharmacognosy,} Phytochemistry, and Natural Products, Faculty of Pharmacy, Universitas Indonesia, Depok, INDONESIA.

${ }^{2}$ Department of Pharmaceutical Technology, Faculty of Pharmacy, Universitas Indonesia, Depok, INDONESIA.

\section{Correspondence}

\section{Berna Elya}

Department of Pharmacognosy,

Phytochemistry, and Natural Products,

Faculty of Pharmacy, Universitas

Indonesia, Depok, INDONESIA.

E-mail: berna.elya@farmasi.ui.ac.id

History

- Submission Date: 27-01-2021;

- Review completed: 03-03-2021;

- Accepted Date: 10-03-2021.

DOI : 10.5530/pj.2021.13.97

Article Available online http://www.phcogj.com/v13/i3

\section{Copyright}

(C) 2021 Phcogj.Com. This is an openaccess article distributed under the terms of the Creative Commons Attribution 4.0 International license.

\begin{abstract}
Introduction: Faloak (Sterculia quadrifida $\mathrm{R}$. Br) is one of the typical plants of East Nusa Tenggara (NTT). Faloak contain flavonoid and polyphenol compounds, and show strong antioxidants activity which potentially correlated with its elastase inhibitory activity. Therefore, in this research, elastase inhibitory activity on various part of Faloak plant was investigated. Objective: The purpose of this research was to investigate the elastase inhibitory activity, determination of total polyphenol, determination of total flavonoids, and also pharmacognosy characterization of Faloak leaves, roots, stems and stem barks. Methods: Sample of leaves, roots, stems, and stem barks were extracted by $70 \%$ ethanol using ultrasound-assisted extraction (UAE). Phytochemical screening, microscopic identification and elastase inhibitory activity testing were performed on the leaves, roots, stems, and stem barks extract. This extract with the highest elastase inhibitory activity was then determined for its total polyphenol content and of total flavonoids content. Results: UAE method with $70 \%$ ethanol successfully extracted active compounds from leaves, stems, roots, and stem barks of Faloak. Extract of all Faloak parts contained alkaloids, flavonoids, tannins, terpenes, and glycosides. The extract of Faloak stem barks showed the strongest elastase inhibitory activity as compared to the extract from other parts, with IC50 of $73.7 \mu \mathrm{g} / \mathrm{mL}$. Alkaloid, flavonoid, tannin, terpene, and glycoside were detected as secondary metabolite in the extract of leaves, roots, stems and stem barks. The extract of Faloak stem barks showed the highest elastase inhibitory activity with $\mathrm{IC}_{50} 73.7 \mu \mathrm{g} / \mathrm{mL}$. The total flavonoids and total polyphenol content of Faloak stem bark extract were respectively $28.75 \mathrm{mg} / \mathrm{gram}$ and $45.25 \mathrm{mg} / \mathrm{gram}$ extract. Conclusion: The $70 \%$ ethanol extract of leaves, roots, stems, and stem barks of Faloak showed elastase inhibitory activity, and stem barks extract showed the strongest activity. Faloak stem barks extract can be considered as potential to be developed as active compound in anti-aging product, both in cosmetic and pharmaceutical dosage forms.

Key words: Elastase inhibitory, Polyphenol, Flavonoids, Sterculia quadrifida.
\end{abstract}

\section{INTRODUCTION}

Sterculia quadrifida R. Br. of Sterculiaceae family is locally known as "Faloak" in East Nusa Tenggara Province, Indonesia. Some parts of Faloak contain flavonoid and polyphenol compounds, and show strong antioxidants activity which potential to be developed as a source of natural antioxidants. ${ }^{1}$ Previous research was carried out by Grace and Siswadi (2019) on the extraction of Faloak stem bark using the maceration method with $70 \%$ ethanol solvent and showed a total flavonoid content (TFC) of $6.618 \mathrm{mg} \pm 0.123 \mathrm{mg}$ quercetin equivalent/gram extract.

There have been several studies on other plants with antioxidants activity which showed that antioxidant activity was potentially correlated with their elastase inhibitory activity. Research by Salem et al. (2020) reported that $R$. officinalis contains flavonoid compounds and high total polyphenol content which correlated with strong antioxidant and anti-aging activity. Thus, it can be used for further development of topical preparations with anti-aging properties. In the study, total polyphenol and total flavonoid levels were directly proportional to the inhibition of elastase activity. The higher the total polyphenol content and total flavonoid levels, the higher the activity inhibition against elastase. ${ }^{2}$

Elastase is an enzyme that is responsible for the breakdown of elastin. ${ }^{3}$ Misregulation of the elastase enzyme is involved in the skin aging process. ${ }^{4}$ Inhibitors of the elastase have the potential to be developed into anti-aging ingredients. Several natural compounds from plants have been shown to inhibit the activity of this enzyme and to promote synthesis of elastin ${ }^{5}$. In the previous research, Rubus Fraxinifolius Stem and Rhus javanica L. contain flavonoids and polyphenol which have antioxidant activity and correlate with elastase inhibitory activity. ${ }^{6,7}$ Some of polyphenols found in plants such as catechin, epicatechin, epigallocatechin, boswellic acid, and flavonoid such as purpurin, quercetin,

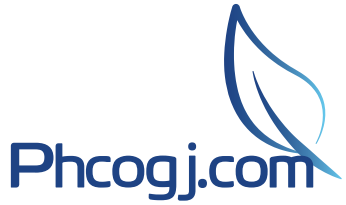

Cite this article: Radjah SY, Putri KS, Elya B. Elastase Inhibitory Activity, Determination of Total Polyphenol and Determination of Total Flavonoids, and Pharmacognosy Study of Faloak Plant (Sterculia quadrifida R.Br) from East Nusa Tenggara-Indonesia. Pharmacog J. 2021;13(3): 758-64. 
kaempferol and myricetin also showed inhibitory activity against elastase. ${ }^{8-10}$. Based on these data, the extract of the Faloak plant part is predicted to be a potential candidate for skin antiaging through the inhibitory effect of the elastase enzyme.

Ultrasound-Assisted Extraction (UAE) has the advantage to increase the yield of the extract with the use of fewer solvents and reduce extraction time $\mathrm{e}^{11,12}$. Based on previous research, the combination of the UAE method and ethanol solvent has successfully used as an efficient extraction method for polyphenol compounds and flavonoids in several plants. ${ }^{12-14}$ Therefore, in this research, four parts of the Faloak plant (leaves, roots, stems, and stem barks) were extracted with $70 \%$ ethanol solvent using the UAE method. Furthermore, phytochemical screening and elastase inhibitory activity tests were carried out on the extract of each part of the plant. Extracts of plant parts that showed the highest elastase inhibitory activity was then determined for its total polyphenol and total flavonoid content.

\section{MATERIALS}

Stem barks, stems, roots, and leaves of Faloak were collected from East Penfui village, Central Kupang district, Kupang District, East Nusa Tenggara Province and was determined at Herbarium Bogoriensis, Biological Research Center of the Indonesian Institute of Sciences in February 2020. The solvent used in research was pro-analysis solvent (ethanol p.a , methanol p.a), 70\% ethanol, Trizma base (Sigma Aldrich No.T1503), N-Succinyl-Ala-Ala-Ala-p-nitroanilide / SANA (Sigma Aldrich SLBR 7591V), porcine pancreas elastase (Sigma Aldrich SLBV 9311), HCl, Aqua demineralisata (Brataco Chemika, Indonesia), DMSO (Merck, Germany), quercetin (Sigma Aldrich, India), Folin Ciocalteau (F9252 / F47641), aqua destillata (Brataco Chemika, Indonesia).

\section{Microscopic observations by scanning electron microscope (SEM) and light microscope}

Microscopic analysis of leaves, roots, stems, and stem barks of Faloak were performed using SEM Model: JSM - IT 200 in the Zoology Field of the Biology Research Centre - Indonesian Institute of Sciences (LIPI), Cibinong.

\section{Extraction}

Leaves, stem barks, stems, roots extract of Faloak were obtained by extraction using the UAE method using an ultrasonic bath and 70\% ethanol as a solvent. Each powder of faloak was put into a container, then filled with $70 \%$ ethanol to the ratio powder $(\mathrm{g})$ : solvent $(\mathrm{mL})=$ 1:20. The 5-gram of leaves, stem barks, stems, and roots powder was soaked in $100 \mathrm{~mL}$ of ethanol $70 \%$ and extracted by an ultrasonic bath with a frequency of $40 \mathrm{kHz}$, temperature $40^{\circ} \mathrm{C}$ for 30 minutes. The extract of Faloak were filtered to take the supernatant, then evaporated using a rotary vacuum evaporator and using a water bath until a thick extract is obtained.

\section{Phytochemical screening}

The identification of compounds in the extract was carried out on $70 \%$ ethanol extract of stem barks, stems, roots and leaves of Faloak. The extracts were subjected to preliminary phytochemical investigation for the detection of following compounds; terpenoids, glycosides, flavonoids, alkaloids, tannins, and saponins. The procedures described by Indonesian Pharmacopoeia $4^{\text {th }}$ edition and Harborne $e^{15,16}$.

\section{Elastase inhibitory activity}

Roots, stem barks, stems, leaves extracts were prepared and diluted into various concentrations. Elastase inhibitory activity assay was performed using an established protocol from Sigma Aldrich with slight modifications according to the previous research. ${ }^{8,17,18}$ Plant extract $20 \mu \mathrm{l}$ in DMSO solution, $130 \mu \mathrm{l}$ Tris $\mathrm{HCl}$ buffer $\mathrm{pH} 8.0$ and, 0.022 unit PPE were incubated within 15 minutes at $25^{\circ}$ C. $0.29 \mathrm{mM}$ SANA substrate was then added and mixed immediately and the mixture was then reincubated within 15 minutes with light protection at room temperature. Quercetin was used as a standard control. The absorbance was measured at $401 \mathrm{~nm}$ using microplate reader versamax. The experiments were performed in triplicate. Elastase inhibitory activity was calculated using the following formula:

Percentage of inhibition $\left.(\%)=\frac{(A-B)-(C-D)}{(A-B)}\right) \times 100$

Where A= Blank absorbance; $\mathrm{B}=\mathrm{Blank}$ control absorbance; $\mathrm{C}=$ Sample absorbance; $\mathrm{D}=$ Sample control absorbance

\section{Determination of total polyphenol}

Determination of polyphenol content was measured on extracts with the highest elastase inhibitor activity (stem barks). The procedures described by Indonesian Herb Pharmacopoeia ${ }^{19}$. Methanol P was added into $200 \mathrm{mg}$ extract up to $25 \mathrm{ml}$. $1.0 \mathrm{~mL}$ of this sample solution is taken, then added with $5 \mathrm{~mL}$ diluted Folin-Ciocalteu LP (7.5\% in aqua destillata), $4 \mathrm{~mL} 1 \% \mathrm{NaOH}$ then incubated at room temperature for 1 hour. The absorbance of this solution was measured using UV-Vis.

\section{Determination of total flavonoids}

Determination of flavonoids content was measured on extracts with the highest elastase inhibitor activity (stem barks). The procedures described by Indonesian Herb Pharmacopoeia. ${ }^{19}$ Ethanol $\mathrm{P}$ was added into $200 \mathrm{mg}$ extract up to $25 \mathrm{ml} .0 .5 \mathrm{~mL}$ of this sample solution is taken, then added with $1.5 \mathrm{~mL}$ of ethanol P, 0,1 mL 10\% AlCl3 P, $0.1 \mathrm{~mL}, \mathrm{Na}$ acetate $1 \mathrm{M}$, and, $2.8 \mathrm{~mL}$ aqua destilata. The total volume of the solution is $5 \mathrm{~mL}$. The solution was shaken and and then incubated at room temperature for $30 \mathrm{~min}$. The absorbance of this solution measurement using UV-Vis.

\section{RESULTS AND DISCUSSION}

\section{Microscopic characterization of plant powder}

The microscopic fragment using SEM were shown in Figures 1- 4.

\section{Extraction}

Faloak were extracted using UAE with 70\% ethanol as solvent.

The extraction results are shown in Table 1.

UAE method on Faloak resulted the highest extract yield from stem barks, followed with extract from roots, leaves and stems. The higher yield of extract indicates the higher concentration of extracted component.

\section{Phytochemical screening}

Phytochemical screening on the extracts showed the presence of flavonoids, glycosides, alkaloids, tannins, terpenes, and saponins, as described in Table 2.

Ethanol extract from all parts of Faloak plant contained flavonoids which potentially exhibit antioxidant activity as well as elastase inhibitory activity. The tannin compound was also detected in all of the extracts, thus we further measured total phenolic concentration.

\section{Elastase inhibitory activity}

The elastase inhibitory activity of extracts from four parts of Faloak plant were investigated, and quercetin was used as the standard compound. The result was shown in Table 3.

Table 3 showed that stem bark extract exhibited the strongest elastase inhibitory activity with IC50 $73.7 \mu \mathrm{g} / \mathrm{mL}$ as compared to the extract 


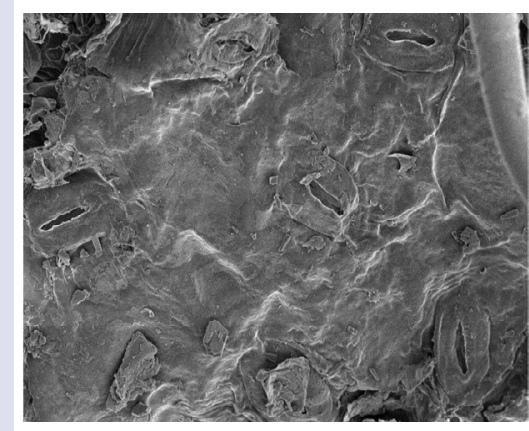

A

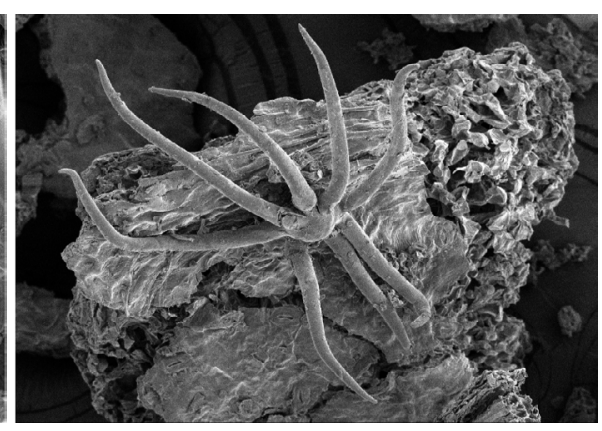

$\mathrm{B}$

Figure 1: Microscopic of Faloak leaves powder. A= Stomata, B= Star shape trichoma.

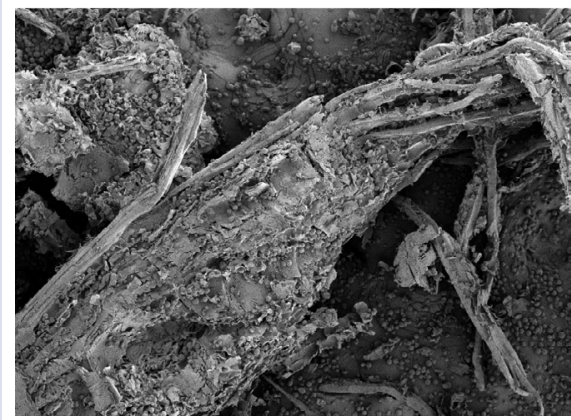

A

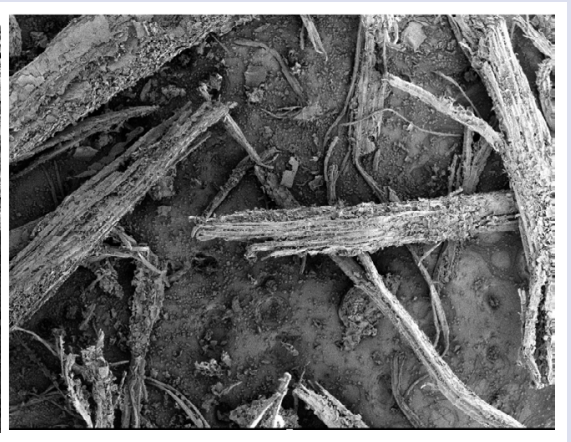

$\mathrm{B}$

Figure 2: Microscopic of Faloak roots powder. $A=$ epidermis, $B=$ Xylem.

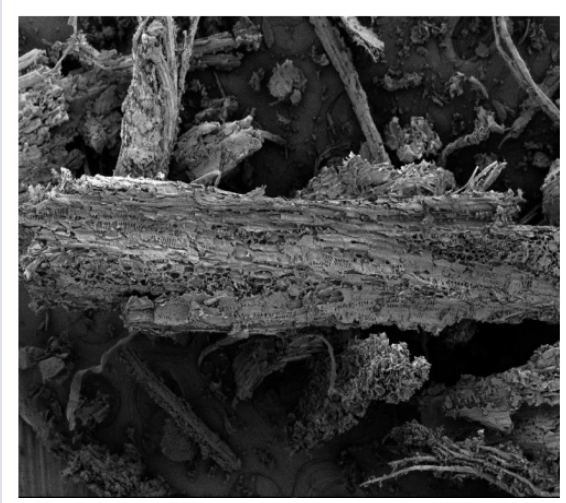

A

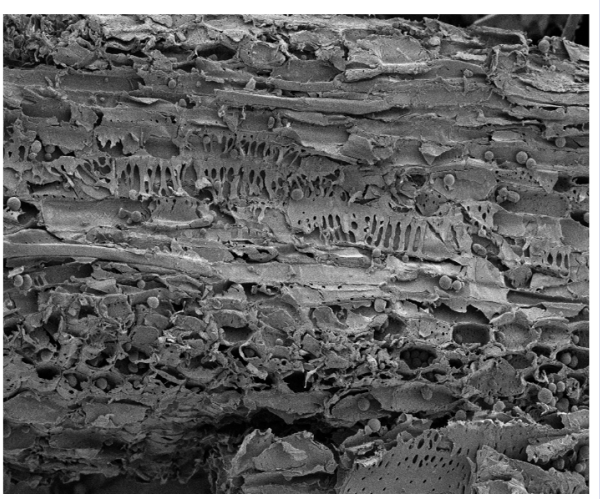

$\mathrm{B}$

Figure 3: Microscopic of Faloak stems powder. $A=$ Xylem, $B=$ Parenchim. 


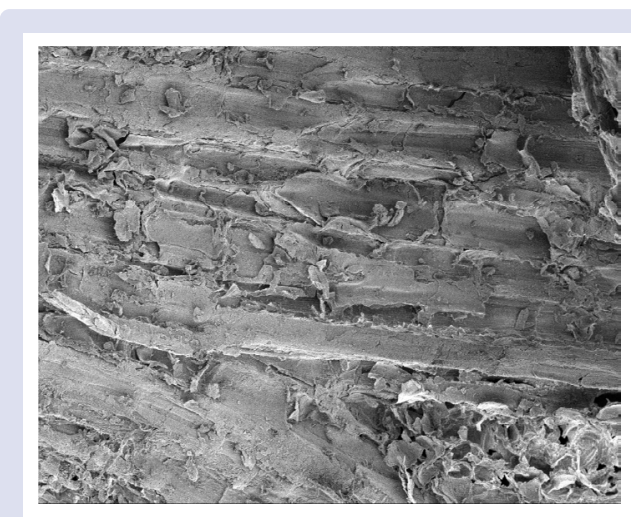

A

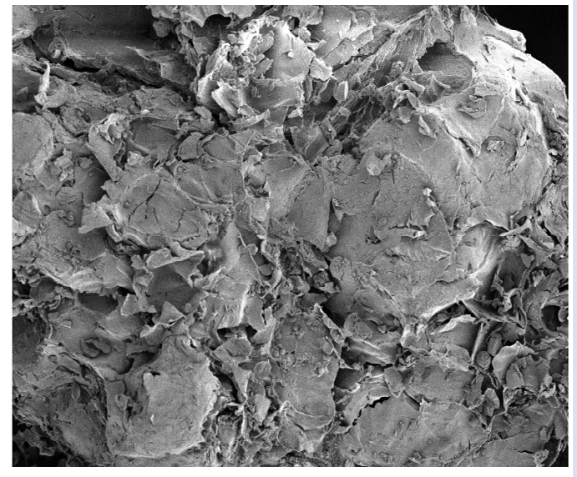

Figure 4: Microscopic of Faloak stem barks powder. $A=$ Epidermis, $B=$ Parenchim.

Table 1: The yield of Faloak extraction.

\begin{tabular}{ccccc}
\hline Result & Leaf & Root & Stem & Stem bark \\
\hline Extract weight (g) & 14.4 & 15.6 & 12.6 & 18 \\
Yield (\%) & 12 & 13 & 10,5 & 15
\end{tabular}

Table 2: Phytochemical screening of extract $70 \%$ ethanol of Faloak plant.

\begin{tabular}{ccccc}
\hline Chemical & \multicolumn{3}{c}{ Results } \\
\cline { 2 - 5 } compound & Leaves & Roots & Stems & Stem barks \\
\hline Flavonoids & + & + & + & + \\
Alkaloids & + & + & + & + \\
Tannins & + & + & + & + \\
Terpenes & + & + & + & + \\
Saponins & - & - & + & + \\
Glycosides & + & + & & +
\end{tabular}

Table 3: Elastase inhibitory activity of Faloak extracts from different part.

\begin{tabular}{cc}
\hline Sample & Elastase inhibitory (IC50) \\
\hline Quercetin & $29.14 \mu \mathrm{g} / \mathrm{mL}$ \\
Faloak stem barks & $73.7 \mu \mathrm{g} / \mathrm{mL}$ \\
Faloak stems & $141.7 \mu \mathrm{g} / \mathrm{mL}$ \\
Faloak roots & $166.3 \mu \mathrm{g} / \mathrm{mL}$ \\
Faloak leaves & $183.04 \mu \mathrm{g} / \mathrm{mL}$
\end{tabular}

from other part of the plant. Elastase is an enzyme which responsible for the breakdown of elastin ${ }^{3}$, thus a compound with inhibitory activity toward elastin can be considered to be developed into anti-aging ingredients. This result of this research indicated that the stem bark extract of Faloak plant with concentration of $73.7 \mu \mathrm{g} / \mathrm{mL}$ can inhibit $50 \%$ of elastase activity, thus this extract showed potential as anti-aging component. As comparison to the Faloak stem bark extract, quercetin as standard showed stronger elastase inhibitory activity with $\mathrm{IC}_{50}$ of $29.14 \mu \mathrm{g} / \mathrm{mL}$.

\section{Determination of total flavonoids and total polyphenol}

Since the extract of Faloak stem bark extract showed the strongest elastase inhibitory activity, total flavonoid and polyphenol content of this stem bark extract were further measured.

Quercetin levels were calculated as total flavonoid and total polyphenol levels in the sample. Standard curve of quercetin for total flavonoid measurement showed linear regression equation $y=0.0019 x+0.0345$ and value of relation coefficient $(r)=0.9979$. Based on the measurement, the average flavonoids content in each gram of extract was $28.75 \pm 0.002$ mg. Meanwhile, standard curve of quercetin for total polyphenol measurement showed linear regression equation $y=0.0052 x+0.0304$ and value of relation coefficient $(r)=0.9952$. Based on the measurement results, the average polyphenol content in each gram of extract was $45.25 \pm 0.002 \mathrm{mg}$. These results indicated that Faloak stem barks extract contained relatively high polyphenol and flavonoid components, and these flavonoids and phenolic are possible to have a role as an elastase inhibitor.

Previous studies showed that flavonoids, such as quercetin, kaempferol, and myricetin, can significantly inhibit elastase proteolytic activity $y^{8,10}$ Other studies also showed that polyphenol inhibit elastase proteolytic activity by forming hydrogen bonds between their hydroxyl group with amino acids in the enzyme, causing a hydrophobic effect that results in a complex or aggregate, insoluble precipitate, which decreases catalytic activity and denatures the enzyme. Polyphenol form hydrogen bonds with amino acids in PPE: serine, histamine, and aspartate residues known as the catalytic triad. ${ }^{20}$ Another plant study reported that contains polyphenol and flavonoids that have the potential to inhibit elastase is Rhus javanica. ${ }^{21}$ The major polyphenol compounds of 
Rhus Javanica have been reported as were gallic acid, methyl gallate, syringic acid, pentagalloylglucose, and protocatechuic acid. ${ }^{22}$ Due to its chemical compound, polyphenols had potent antioxidants to scavenge Reactive Oxygen Species (ROS). Polyphenols may have inhibited activity of proteolytic enzyme such as elastase. ${ }^{8}$ Based on previous research, species of Rhus javanica in Jeju Island had strong anti-aging ability by inhibiting elastase $80.8 \pm 0.5$ at $80 \%$ ethanol leaf extract 500 $\mu \mathrm{g} / \mathrm{ml}$ and IC50 $=70.5 \mu \mathrm{g} / \mathrm{mL} .{ }^{21}$ Research conducted by Mardhiyah et al., 2020 reported that the water fraction of $A$. carambola Depok leaves with a total polyphenol and flavonoid content of $115.68 \mathrm{mg}$ gallic acid equivalent g extract and $9.15 \mathrm{mg}$ equivalent quercetin / g extract can inhibit proteolytic activity elastase and prevent premature skin aging. ${ }^{2}$

Based on the result on this research on elastase inhibitory activity, total flavonoid and total polyphenol content, it is considered that Faloak stem bark extract can be considered as potential to be developed as active compound in anti-aging product, both in cosmetic and pharmaceutical dosage forms.

\section{CONCLUSION}

UAE method with $70 \%$ ethanol successfully extracted active compounds from leaves, stems, roots and stem barks of Faloak. Extract of all Faloak parts contained alkaloids, flavonoids, tannins, terpenes, and glycosides. The extract of Faloak stem barks showed the strongest elastase inhibitory activity as compared to the extract from other parts, with $\mathrm{IC}_{50}$ of $73.7 \mu \mathrm{g} / \mathrm{mL}$. The total flavonoid and total polyphenol content of faloak stem barks extract were respectively $28.75 \mathrm{mg} / \mathrm{gram}$ and 45.25 $\mathrm{mg} /$ gram extract.

\section{ACKNOWLEDGEMENT}

The author would like to acknowledge Universitas Indonesia for funding this research through "Publikasi Terindeks Internasional (PUTI) Q3 Universitas Indonesia" Grant with contract number NKB-1813/UN2. RST/HKP.05.00/2020.

\section{CONFLICTS OF INTEREST}

There are no conflicts of interest.

\section{REFERENCES}

1. Grace Serepina Saragih, Siswadi Siswadi. Antioxidant Activity of Plant Parts Extracts From Sterculia quadrifida R.Br. Asian Journal of Pharmaceutical and Clinical Research. 2019;143-8.

2. Mardhiyah S, Elya B, Noviani A. Elastase activity inhibition by the most active fraction of star fruit (Averrhoa carambola L.) leaves from three west java regions. International Journal of Applied Pharmaceutics. 2020;12(1):101-6.

3. Imokawa G, Ishida K. Biological mechanisms underlying the ultraviolet radiation-induced formation of skin wrinkling and sagging I: Reduced skin elasticity, highly associated with enhanced dermal elastase activity, triggers wrinkling and sagging. International Journal of Molecular Sciences. 2015;16(4):7753-75

4. Korkmaz B, Horwitz MS, Jenne DE, Gauthier F. Neutrophil elastase, proteinase 3, and cathepsin Gas therapeutic targets in human diseases. Pharmacological Reviews. 2010;62(4):726-59.
5. Shoko T, Maharaj VJ, Naidoo D, Tselanyane M, Nthambeleni $R$, Khorombi E, Apostolides, Z. Anti-aging potential of extracts from Sclerocarya birrea (A. Rich.) Hochst and its chemical profiling by UPLC-Q-TOF-MS. BMC Complementary and Alternative Medicine. 2018;18(1):1-14.

6. Desmiaty Y, Saputri FC, Hanafi M, Prastiwi R, Elya B. Anti-elastase, anti-tyrosinase, and anti-oxidant of Rubus fraxinifolius stem methanolic extract. Pharmacognosy Journal. 2020;12(2).

7. Anggraini NB, Elya B, Iskandarsyah. Anti-elastase, antioxidant, total phenolic and total flavonoid content of macassar kernels (Rhus javanica L) from pananjung pangandaran nature tourism parkIndonesia. Journal of Natural Remedies. 2020;20(1):61-7.

8. Wittenauer J, Mäckle S, Sußmann D, Schweiggert-Weisz U, Carle R. Inhibitory effects of polyphenols from grape pomace extract on collagenase and elastase activity. Fitoterapia. 2015;101:179-87.

9. Thring TSA, Hili P, Naughton DP. Anti-collagenase, anti-elastase and anti-oxidant activities of extracts from 21 plants. BioMed Central. 2009;9:1-11.

10. Kanashiro A. Elastase release by stimulated neutrophils inhibited by flavonoids: importance of the catechol group. Zeitschrift für Naturforschung C. 2007;56:357-61.

11. Chemat F, Tomao V, Virot M. Handbook of Food Analysis Instruments. Ultrasound-Assisted Extraction in Food Analysis. Boca Raton, FL: CRC Press. 2008;85-94.

12. Panja, P. Green extraction methods of food polyphenols from vegetable materials. Food Science. 2017;17:1-10.

13. Jang M, Asnin L, Nile SH, Keum YS, Kim HY, Park SW. Ultrasoundassisted extraction of quercetin from onion solid wastes. International Journal of Food Science and Technology. 2013;48(2):246-52

14. Carrera C, Ruiz-Rodríguez A, Palma M, Barroso CG. Ultrasound assisted extraction of phenolic compounds from grapes. Analytica Chimica Acta. 2012;732:100-4.

15. Ministry of Health Republic of Indonesia. Indonesia Pharmacopoeia 4th Edition. Jakarta: Ministry of Health Republic of Indonesia. 1995.

16. Harborne J. A Guide to Modern Techniques of Plant Analysis. Phytochemical Methods. Chapman and Hall London. 1998.

17. Popoola OK, Marnewick JL, Rautenbach F, Ameer F, Iwuoha El, Hussein AA. Inhibition of oxidative stress and skin aging-related enzymes by prenylated chalcones and other flavonoids from Helichrysum teretifolium. Molecules. 2015;20(4):7143-55.

18. Putri IR, Handayani R, Elya B. Anti-Elastase Activity of Rumput Teki (Cyperus rotundus L.) Rhizome Extract. Pharmacognosy Journal. 2019;11(4):754-8.

19. Ministry of Health Republic of Indonesia. Indonesia Herbal Pharmacopoeia, 2nd Edition. Jakarta: Ministry of Health Republic of Indonesia. 2017.

20. Brás NF, Gonçalves R, Mateus N, Fernandes PA, Ramos MJ, de Freitas $V$. Inhibition of pancreatic elastase by polyphenolic compounds. J Agric Food Chem, 58:10668-76.

21. Moon J, Yim E, Song G, Lee NH, Hyun C. Screening of elastase and tyrosinase inhibitory activity from Jeju Island plants. EurAsian Journal of BioSciences. 2010.4(1):41-53.

22. Ha SJ, Lee J, Kim H, Song K-M, Lee NH, Kim YE. Preventive effect of Rhus javanica extract on UVB-induced skin inflammation and photoaging. Journal of Functional Foods. 2016;27:589-99. 


\section{GRAPHICAL ABSTRACT}

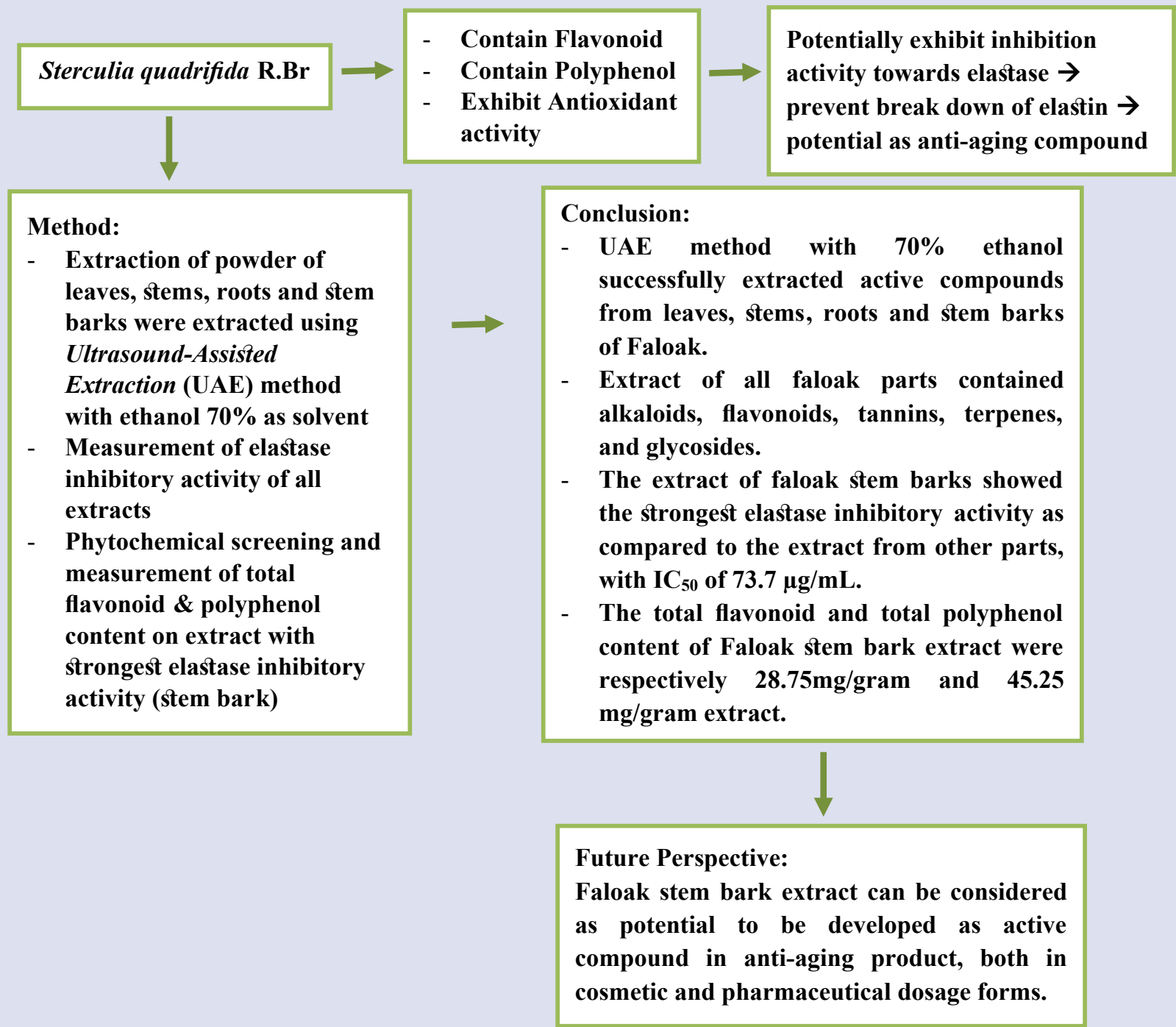

\section{ABOUT AUTHORS}

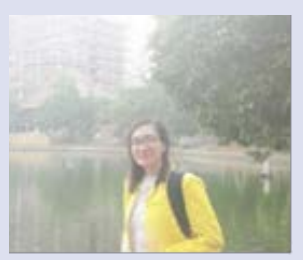

Sofiah Yunita Radjah is a Pharmacist and Magister Pharmacy Student at the Faculty of Pharmacy, Universitas Indonesia, Kampus UI Depok, West Java 16424, Indonesia. She conducted research on pharmacognosy study of natural product and biotechnology of pharmacy.

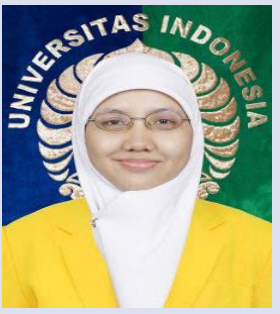

Kurnia Sari Setio Putri is a lecturer at Faculty of Pharmacy, Universitas Indonesia. She gained her doctoral degree from University of Groningen, The Netherlands in 2019. Her main research interest are in pharmaceutical technology, especially in developing modified/ advanced pharmaceutical dosage forms. 


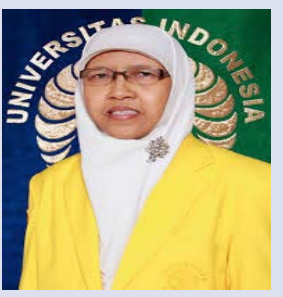

Berna Elya is a Professor and Lecturer at the Faculty of Pharmacy, Universitas Indonesia, Kampus UI Depok, West Java 16424, Indonesia. She develops works in the area of Pharmacognosy and Phytochemistry (Natural Product).

Cite this article: Radjah SY, Putri KS, Elya B. Elastase Inhibitory Activity, Determination of Total Polyphenol and Determination of Total Flavonoids, and Pharmacognosy Study of Faloak Plant (Sterculia quadrifida R.Br) from East Nusa Tenggara-Indonesia. Pharmacog J. 2021;13(3): 758-64. 